\title{
PENGARUH PEMBERIAN AROMATHERAPI JAHE TERHADAP PENURUNAN MUAL DAN MUNTAH PADA PASIEN KANKER YANG MENJALANI KEMOTERAPI DI RUMAH SAKIT UMUM IMELDA PEKERJA INDONESIA MEDAN TAHUN 2017
}

\author{
Rostinah Manurung, Tri Utami Adriani \\ Dosen Prodi S1Keperawatan, STIKes Imelda, Jalan Bilal Nomor 52 Medan; \\ Alumni STIKes Imelda Jalan Bilal Nomor 52 Medan \\ E-mail: rostinahmanurung@gmail.com
}

\begin{abstract}
ABSTRAK
Aromaterapi jahe merupakan salah satu terapi komplementer pada penderita kanker yang mengalami mual muntah setelah menjalani kemoterapi. Mual dan muntah dapat menurunkan aktivitas sehari-hari dan menyebabkan pasien kanker hanya dapat berbaring ditempat tidur dan tidak dapat memenuhi kebutuhan dalam beraktivitas. Tujuan penelitian untuk mengidenifikasi pengaruh aromaterapi jahe terhadap mual muntah pada pasien kanker. Desain penelitian adalah pre-experimental dengan desain post test only design. Tehnik pengambilan sampel dengan accidental sampling yang terdiri dari 30 responden. . Hasil penelitian menunjukkan bahwa pengaruh pemberian aromtherapi jahe di Rumah Sakit Umum Imelda Pekerja Indonesia Medan mayoritas dengan kategori baik sebanyak 23 responden (76,6 \% )dan kategori minoritas atau kurang sebanyak 4 responden( 13,3\%) . kesimpulan hasil penelitian adalah responden yang menjalani kemoterapi di Rumah Sakit Umum Imelda Pekerja Indonesia Medan mengalami penurunan mual dan muntah sekitar 76,6 \% . hal ini disebabkan karena aromaterapi jahe yang dapat memblok serotonin yaitu suatu neurotransmitter yang disintesiskan pada neuro-neuro serotonergis dalam sistem saraf pusat dan sel-sel enterokromafin yang dapat memberikan perasaan nyaman sehing ga dapat mengatasi mual dan muntah.
\end{abstract}

Kata kunci: Aromaterapi Jahe, Mual dan Muntah, Kanker, Kemoterapi.

\section{PENDAHULUAN}

Kanker merupakan salah satu penyakit yang telah menjadi masalah kesehatan masyarakat di dunia maupun di Indonesia. Setiap tahun, 12 juta orang diseluruh dunia menderita kanker dan 7,6 juta di antaranya meninggal dunia karena kanker. Di Amerika insiden penyakit kanker sekitar 1.638.910 kasus baru kanker didiagnosa pada tahun 2012, sekitar 577.190 orang meninggal karena kanker serta lebih dari 1500 orang meninggal karena kanker setiap harinya.

Prevalensi kanker tertinggi di Yogyakarta berdasarkan diagnosis dokter atau hasil Riset Kesehatan Dasar (Riskesdas) tahun 2013 sebesar 4,1 per 1000 penduduk dan di Jawa Tengah menempati urutan kedua sebesar 2,1 per 1000 penduduk. Kanker merupakan penyebab kematian nomor 7 $(5,7 \%)$ setelah stroke, TB, hipertensi, cedera, perinatal, dan DM. Saluran empedu intrahepatik $(9,69 \%)$, Leukemia $(7,42 \%)$, dan Limfoma non Hodgkin $(6,69 \%)$ (Depkes RI, 2013).

Beberapa pengobatan atau terapi untuk penderita kanker yaitu pembedahan, radioterapi, kemoterapi dan terapi biologis. Pembedahan dilakukan bila tumornya terlokalisasi dalam keadaan anatomis yang terbaik. Radioterapi paling bermanfaat untuk tumor terlokalisasi yang tidak dapat direseksi atau untuk tumor seperti Hodgkin yang umumnya menyebar ke tempat bersebelahan yang dapat diperkirakan. Kemoterapi merupakan terapi sistemik pertama untuk setiap kanker (Alpers, 2006). Kemoterapi dapat menimbulkan mual dan muntah melalui beberapa mekanisme yang bervariasi dan serangkaian yang komplek. Pertama, pusat muntah dapat terjadi secara tidak langsung oleh stimulus tertentu yang dapat 
mengaktifkan Chemoreseptor Trigger Zone (CTZ) di medulla, peran CTZ sebagai chemosensor, area ini kaya akan berbagai reseptor neurotrasmiter seperti histamine, ser otonin, dopamine, opiate, neurokinin dan benzodiazepine, sedangkan agen kemoterapi menyebabkan proses muntah melalui salah satu dari reseptor tersebut. Kedua, kemoterapi dapat menyebabkan gangguan pada mukosa gastrointestinal dan menyebabkan pengeluaran neurotrasmitter termasuk 5HT3 (5 hydroxytriptamine). Hal ini menyebabkan mual dan muntah melalui jalur perifer yang dimediasi oleh saraf vagus. Ketiga, gejala ini disebabkan karena pengaruh neurohormonal melalui terganggun ya arginin vasopressin dan prostaglandin. Keempat, mual dan muntah dimediasi oleh kecemasan yang memberikan pengaruh terhadap sistem saraf pusat termasuk pusat muntah (Wood, at al, 2007).

Mual dan muntah adalah efek samping yang paling umum dan tidak menyenangkan pada pasien setelah menjalani pengobatan kemoterapi. Insiden mual dan muntah karena efek samping kemoterapi adalah 70-80\%, beberapa kondisi gejala-gejala yang berhubungan dengan pemberian kemoterapi dapat menurunkan aktivitas sehari-hari pasien kanker dan menyebabkan mereka hanya dapat terbaring ditempat tidur dan tidak bisa memenuhi kebutuhan mereka dalam beraktivitas (Lee, 2008).

Salah satu tindakan keperawatan mandiri seorang perawat yaitu memberikan rasa nyaman untuk mengurangi atau menghilangk an ketidaknyamanan akibat efek samping kemoterapi dengan pemberian terapi komplementer. Aromaterapi sebagai bagian dari terapi komplementer dapat digunakan untuk meningkatkan kualitas hidup pasien kanker (Boehm, at, al., 2012). Aromaterapi mengacu pada penggunaan minyak esensial yang diekstrak dari akar, bunga, daun dan batang tanaman, serta dari pohon tertentu. Minyak tumbuhan dapat dipecah menjadi bahan kimia seperti alkohol, keton dan fenol, yang dianggap memiliki sifat terapeutik. Tehnik aromaterapi inhalasi dapat digunakan untuk meningkatkan relaksasi dan kenyamanan (Jaelani, 2009). Kohatsu (2008) menyatakan pemakaian minyak esensial secara inhalasi merupakan metode yang dinilai paling efektif, sangat praktis dan memiliki khasiat yang langsung dapat dirasakan efeknya dibanding dengan tehnik yang lain, tehnik inhalasi ini lebih mudah untuk masuk ke dalam tubuh tanpa melalui proses absorbsi membran sel, molekulmolekul uap akan langsung mengenai reseptor penghidu yang berada pada rongga hidung dan langsung terhubung dengan saraf olfaktorius.

Kolcaba mengenalkan teori kenyamanan sebagai middle range theory karena mempunyai tingkat abstraksi yang rendah dan mudah diaplikasikan dalam praktik keperawatan. Kenyamanan adalah sebuah tujuan yang sangat diharapkan oleh pasien kanker, dan karenanya menghadirkan tujuan yang penting bagi pelayanan keperawatan (Miaskowski, et, al., 2005). Kolcaba menilai kenyamanan dengan membuat struktur taksonomi yang bersumber pada tiga tipe kenyamanan yaitu reliefe, ease, dan transcendence. Kolcaba mengkaitkan ketiga tipe kenyamanan tersebut dengan empat konteks kenyamanan yaitu fisik, berkaitan dengan sensasi jasmani; Psikospiritual, berkaitan dengan kesadaran diri dan konsep diri; Lingkungan, berkaitan dengan keadaan sekitar; dan sosial berkaitan dengan hubungan interpersonal, keluarga dan sosial (Sitzman \& Eichelberger, 2011). Tindakan intervensi nonfarmakologi yaitu dengan pemberian aromaterapi jahe ini merupakan bagian dari intervensi comfort yang tujuan memberikan kenyamanan secara fisik pada pasien kanker yang menjalani kemoterapi dengan mengurangi atau menghilangkan mual dan muntah akibat kemoterapi. Teknis tindakan ini didesain untuk membantu mempertahankan atau mengembalikan fungsi fisik dan kenyamanan, serta mencegah komplikasi (Kolcaba dan DiMarco, 2005).

Hasil studi yang dirilis pada tahun 2005 oleh American Massage Therapy Association (AMTA) menunjukkan bahwa sekitar 47 juta atau $36 \%$ orang Amerika dewasa telah menggunakan beberapa bentuk pengobatan 
komplementer dan Alternatif atau Complementary and Alternative Medicine (CAM) (Barnes et al. 2004). Menurut Eisenberg et al. (1998), meningkatnya popularitas pengobatan komplementer dan alternatif mencerminkan perubahan kebutuha $\mathrm{n}$ dan nilai-nilai di masyarakat modern pada umumnya. Beberapa terapi CAM yang paling umum digunakan adalah doa (43\%), herbal $(18,9 \%)$, latihan pernapasan $(11,6 \%)$, meditas i $(7,6 \%)$, perawatan chiropractic $(7,5 \%)$, yoga $(5,1 \%)$, dan pijat (5.0\%) (Barnes et al. 2004).

Aromaterapi jahe dapat menjadi pilihan untuk meningkatkan kenyamanan pada pasien yang menjalani kemoterapi dalam mengatasi efek dari kemoterapi. Kandungan didalam jahe terdapat zingiberena (zingirona) , zingiberol, bisabilena, kurkumen, zingirol, flandrena, vitamin A, yang dapat memblok serotonin yaitu suatu neurotransmitter yang disintesiskan pada neuro-neuro serotonergis dalam sistem saraf pusat dan sel-sel enterokromafin yang dapat memberikan perasaan nyaman sehingga dapat mengatasi mual muntah (Ahmad, 2013). Hasil penelitian yang dilakukan oleh Ryan, at, al., (2009) dari University of Program Clinical Oncology Pusat Kanker Rochester Community (URCC CCOP) di Amerika tentang manfaat jahe pada pasien kanker yang menerima kemoterapi dengan metode random double blind pada 644 pasien menyimpulkan bahwa suplementasi jahe secara signifikan mengurangi mual akut yang disebabkan kemoterapi.

Hasil studi pendahuluan yang dilakukan di Rumah Sakit Umum Imelda Pekerja Indonesia Tahun 2017, data pasien yang menjalani kemoterapi dalam empat bulan terakhir sebanyak 40 pasien. Penelitian tentang pemberian aromaterapi sebagai salah satu tindakan keperawatan dan terapi pelengkap untuk mual dan muntah belum pernah dilakukan di Rumah Sakit Umum Imelda Pekerja Indonesia Medan. Berdasarkan hasil wawancara peneliti terhadap pasien kanker yang menjalani kemoterapi di ruang kemoterapi, keluhan yang sering dirasakan setelah kemoterapi adalah rasa mual dan muntah, tindakan untuk mengatasi keluhan mual dan muntah hanya diberikan obat antiemetik.

Berdasarkan fenomena diatas dapat disimpulkan bahwa pasien yang menderita kanker dan mendapatkan kemoterapi dapat menimbulkan berbagai macam efek samping yang tidak menyenangkan bagi pasien. Salah satu efek samping akibat pemberian kemoterapi adalah mual dan muntah. terapi untuk mengurangi rasa mual dan muntah pasien diberikan antiemetik dan tindakan keperawatan mandiri seorang perawat dalam mengurangi atau menghilangkan ketidaknya manan akibat efek samping kemoterapi adalah dengan pemberian terapi aromaterapi jahe, penelitian tentang penggunaan jahe sebagai terapi komplemeter untuk menurunka n mual dan muntah akibat kemoterapi pada pasien kanker sudah banyak dilakukan di Luar Negeri, peneliti belum menemukan penggunaan aromaterapi jahe untuk menurunkan mual dan muntah akibat kemoterapi di Indonesia, sehingga peneliti tertarik untuk melakukan penelitian tentang pengaruh aromaterapi jahe terhadap mual dan muntah akibat kemoterapi.

\section{Rumusan Masalah}

Pasien yang mendapatkan kemoterapi sering mengalami mual dan muntah akibat kemoterapi. Pemberian antiemetik sebagai terapi farmakologi untuk mengurangi rasa mual dan muntah. Terapi komplementer yaitu dengan aromaterapi jahe dikenal dapat mengurangi atau menghilangkan mual dan muntah. pemberian antiemetik bersamaan dengan aromaterapi jahe diharapkan mampu untuk menurunkan mual dan muntah sehingga pasien meningkatkan kenyamanan selama pengobatan kanker. Adapun rumusan masalah dalam penelitian ini adalah adalah "Bagaimanakah pengaruh aromaterapi jahe terhadap penurunan mual dan muntah akibat kemoterapi pada pasien kanker"?

\section{Tujuan Penelitian}

Mengetahui Pengaruh Pemberian Aromaterapi Jahe Terhadap Penurunan Mual dan Muntah Pada Pasien Kanker Yang Menjalani Kemoterapi di Rumah Sakit 
Umum Imelda Pekerja Indonesia Medan Tahun 2017.

\section{Manfaat Penelitian}

1. Bagi pelayanan keperawatan

Pemberian aromaterapi jahe dapat bermanfaat mengurangi atau menghilang kan mual dan muntah akibat kemoterapi dan dapat dijadikan sebagai bagian dari intervensi keperawatan dalam merawat pasien kanker yang menjalani pengobata n kemoterapi, sehingga kualitas pemberi an asuhan keperawatan menjadi lebih baik.

2. Bagi Rumah sakit

Hasil penelitian yang diperoleh diharapkan dapat memberikan informasi dalam mengenai pengaruh pemberian aromatherapi jahe terhadap penurunan mual dan muntah pada pasien kanker yang menjalani kemoterapi di Rumah Sakit Imelda Umum Pekerja Indonesia Medan.

3. Bagi pendidikan keperawatan

Keperawatan sebagai suatu profesi perlu mengembangkan praktik keperawatan mandiri dengan menerapkan terapi komplemeter yaitu penggunaan aromater api jahe untuk mengurangi atau menghilangkan mual muntah akibat kemoterapi, serta hasil penelitian ini diharapkan dapat memperkaya sumber literature keperawatan terkait terapi non farmakologi untuk mengurangi mual dan muntah akibat kemoterapi pada pasien kanker.

4. Bagi Penelitian Keperawatan

Hasil penelitian ini dapat menjadi dasar pengembangan penelitian selanjutnya tentang pengaruh aromaterapi jahe terhadap mual dan muntah akibat kemoterapi pada pasien kanker dan dapat menjadi kerangka acuhan bagi peneliti selanjutnya serta memberikan informasi awal bagi pengembangan penelitian dimasa yang akan datang.
METODE

Jenis dan Desain Penelitian

Jenis penelitian ini adalah jenis penelitian quasi-experimental dengan rancangan pre test-post test one group only design yang bertujuan untuk mengetahui pengaruh pembe rian aromatherapi jahe terhadap penurunan mual dan muntah pada pasien kanker yang menjalani kemoterapi di Rumah Sakit Umum Imelda Pekerja Indonesia Medan Tahun 2017.

Skema 1. Rancangan Penelitian

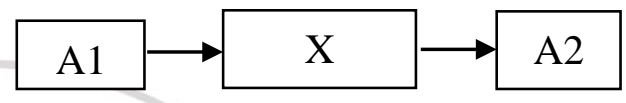

Keterangan:

A1 = Mual dan muntah sebelum diberikan aromatherapi jahe

A2 = Mual dan muntah setelah diberikan aromatherapi jahe

$\mathrm{X}=$ Intervensi (aromatherapi jahe)

\section{Lokasi Penelitian}

Lokasi penelitian dengan judul Pengaruh Pemberian Aromatherapi Jahe Terhadap Penu runan Mual dan Muntah pada Pasien Kanker Yang Menjalani Kemoterapi di Rumah Sakit Imelda Umum Pekerja Indonesia Medan Tahun 2017, alasan peneliti memilih memilih Rumah Sakit Umum Imelda Pekerja Indonesi a sebagai tempat penelitian karena Rumah Sakit Umum Imelda Pekerja Indonesia memilki jarak yang tidak jauh dari tempat tinggal peneliti dan di Rumah Sakit Umum Imelda pekerja Indonesia memilki pasien yang Cukup Untuk menjadi sampel dalam penelitian ini mengenai pasien kanker yang menjalani tindakan kemoterapi.

\section{Waktu Penelitian}

Penelitian dilakukan pada bulan JanuariApril 2017.

\section{Populasi}

Populasi dalam penelitian ini adalah pasien kanker yang menjalani kemoterapi di Rumah Sakit Umum Imelda Pekerja Indonesi 
a bulan januari sampai bulan april sebanyak 40 pasien.

\section{Teknik Sampling}

Tehnik pengambilan sampel pada penelitian ini dilakukan secara Accidental sampling yaitu pengambilan responden yang kebetulan ada atau tersedia disuatu tempat sesuai dengan kompleks penelitian. (Notoad modjo, 2010).

\section{Sampel}

Sampel adalah sebagian dari keseluruha $\mathrm{n}$ objek yang diteliti dan dianggap mewakili seluruh populasi. Dengan kata lain sampel adalah elemen - elemen populasi yang dipilih berdasarkan kemampuan mewakilinya (Setia di, 2007). Dalam penelitian ini teknik penga mbilan sampel menggunakan stratified rando $m$ sampling yaitu pengambilan sampel secara acak stratifikasi. Jumlah sampel dalam penelitian ini sebanyak 30 orang. Kriteria sampel dalam penelitian berdasarkan kriteria inklusi (kriteria yang layak diteliti) sebagai berikut:

1. Pasien kanker yang bersedia menjadi responden .

2. Pasien kanker yang menjalani tindakan kemoterapi di Rumah Sakit Imelda Pekerja Indonesia Medan.

3. Pasien yang kanker yang kooperatif.

\section{Teknik Pengumpulan Data}

Sebelum proses pengumpulan data dilakukan, tahap awal dalam pengumpulan data adalah persiapan untuk kelancaran pelaksanaan penelitian berupa surat ijin penelitian dari institusi dari Stikes Imelda Medan Prodi S-1 Keperawatan. Surat penelitian diberikan kepada Rumah Sakit Umum Imelda Pekerja Indonesia Medan, dimana penelitian dilakukans etelah persyaratan terpenuhi, selanjutnya dilakukan proses pengambilan data untuk memperoleh data yang dibutuhkan dalam penelitian ini, maka diberikan surat persetujuan menjadi responden yang menjelaskna tentang kerahasiaan data dan hasil peneltian tidak berdampak negatif bagi fisik dan psikis responden tanpa unsur keterpaksaan. Instrumen yang digunakan dalam penelitian ini degan menggunakan angket atau kuesioner dan peneliti membaginya langsung kepada responden yang ingin ditelliti terlebih dahulu memberi penjelasan kepada pasien tentang maksud dan tujuan penelitian.

\section{Data Primer}

Data yang digunakan sendiri oleh peneliti dengan melakukan eksperimen kepada pasien yang menjalani kemoterapi berupa pretest dan posttest dengan control group dengan menggunakan kuesioner yang disusun berdasarkan konsep tertulis.

\section{Data Sekunder}

Data yang diperoleh dari pihak institusi yang secara rutin mengumpulkan data, data ini dari bagian rekam medik Rumah Sakit Umum Imelda Pekerja Iindonesia Medan.

\section{Data Tersier}

Data yang diperoleh dari hasil penelitian dan jurnal yang telah dipublikasikan.

\section{Variabel Penelitian}

Variabel penelitian adalah karakteristik yang diamati dan mempunyai variasi nilai dan merupakan operasionalisasi dari suatu konsep agar dapat diteliti secara empiris atau ditentukan tingkatannya (Setiadi, 2007).

\section{Defenisi Operasional}

Defenisi operasional adalah unsur penelitian yang menjelaskan bagaimana cara menentukan variabel-variabel, sehingga defenisi operasional ini merupakan suatu informasi ilmiah yang akan membantu penelit i lain yang ingin menggunakan variabel yang sama (Setiadi, 2007). 
Tabel 1. Definisi Operasional Penelitian

\begin{tabular}{|c|c|c|c|c|}
\hline $\begin{array}{l}\text { Variabel } \\
\text { Penelitian }\end{array}$ & Definisi Penelitian & Cara Ukur & $\begin{array}{l}\text { Hasil } \\
\text { Ukur }\end{array}$ & $\begin{array}{l}\text { Skala } \\
\text { Ukur }\end{array}$ \\
\hline $\begin{array}{l}\text { Variabel } \\
\text { Independen: } \\
\text { Aromatherapy } \\
\text { Jahe }\end{array}$ & $\begin{array}{l}\text { Aromaterapi jahe dapat menjadi pilihan untuk } \\
\text { meningkatkan kenyamanan pada pasien yang } \\
\text { menjalani kemoterapi dalam mengatasi efek } \\
\text { dari kemoterapi yaitu mual dan muntah,, teraphi } \\
\text { minuman jahe hangat ini diberikan selama dua } \\
\text { hari dengan frekuensi } 3 \text { x perhari. }\end{array}$ & Observasi & - & Nominal \\
\hline $\begin{array}{l}\text { Variabel } \\
\text { Dependen: } \\
\text { Mual dan } \\
\text { muntah }\end{array}$ & $\begin{array}{l}\text { Mual dan muntah merupakan manifestasi dini } \\
\text { yang sering ditemukan dari toksisitas obat } \\
\text { kemoterapi. Etiologi mual dan muntah dari } \\
\text { banyak masalah yang berbeda, oleh karena itu } \\
\text { pengatasannya juga berbeda, bisa sederhana } \\
\text { atau bisa juga kompleks }\end{array}$ & Kuesioner & - & Ordinal \\
\hline
\end{tabular}

\section{Teknik Pengukuran}

Teknik pengukuran pada setiap variabel adalah dengan mengajukan 20 pertanyaan yaitu 5 pertanyaan untuk aromatherapi jahe, 5 pertanyaan untuk mual dan muntah, 5 pertanyaan untuk kanker dan 5 pertanyaan untuk kemoterapi dalam bentuk kuesioner kepada responden dan menggunakan skala Guttman yaitu apabila jawaban responden bernilai benar bernilai 1 sedangkan apabila jawaban responden salah diberi nilai 0 dengan menggunakan rumus formula Range.

$$
I=\frac{\mathrm{R}}{\mathrm{K}}=\frac{\text { Skor maksimal-skor minimal }}{\text { kelas }}
$$

Keterangan:

I = Interval Kelas

$\mathrm{R}$ = Jarak Kelas ( Skor Maksimal - Skor

Minimal )

$\mathrm{K}$ = Jumlah ( Kategori )

Sedangkan untuk mengetahui persentase jawaban responden sesuai dengan kriteria responden dengan menggunakan rumus yang dikemukakan oleh Irchan ( 2009 ) sebagai berikut:

$$
\mathrm{P}=\frac{F}{N} \times 100 \%
$$

Keterangan:

$\mathrm{P} \quad=$ Persentase

$\mathrm{F}$ = Jumlah Jawaban Benar

$\mathrm{N}$ = Jumlah Soal

\section{Etika Penelitian}

Selama penelitian, responden dilindungi daengan memperhatikan aspek-aspek selfdetermination, privacy and anonmymity, benefience maleficience, justice (Polit \& Beck, 2013). Penelitian ini dilakukan setelah mendapatkan persetujuan dengan menekanka $n$ masalah etika sebagai berikut:

1. Tekad Individu (Self determination)

Prinsip self determination dijelaskan bahwa responden (respondendan keluarg a) diberi kebebasan oleh peneliti untuk menentukan keputusan sendiri, Peneliti menanyakan kesediaan responden, setela $\mathrm{h}$ setuju respon di minta untuk menandat angani lembar persetujuan menjadi subjek penelitian atau informed consent yang disediakan.

2. Kerahasiaan (Privacy and anonmymity) Prinsip etik privacy anonmymity dalam peneitian ini yaitu menjaga kerahasiaan informasi responden dengan tidak mencantumkan nama, tetapi hanya menuliskan kode inisial dan hanya digunakan untuk kepentingan peneliti.

3. Kebaikan (Benefience)

Prinsip ini memberikan keuntungan dengan cara mencegah dan menjauhkan bahaya, membebaskan responden dari eksploitasi serta menyeimbangkan antara keuntungan dan resiko. 
4. Tidak Merugikan (Malefience)

Prinsip ini menekankan peneliti untuk tidak melakukan tindakan yang menimbulkan bahaya bagi responden yaitu tidak memaksakan lansia untuk melakukan hal-hal yang terlalu berat dalam melaksanakan terapi relaksasi otot progresif, tidak memandang respondense bagai objek, tidak menghina/mencaci maki, dan memanfaatkan respondendan tidak membahayakan respondenkarena kelalaian.

5. Keadilan (Justice)

Prinsip keadilan dalam penelitian ini yaitu dengan memberikan keadilan bagi responden dan memberikan perlakuan sama kepada semua responden tanpa membeda-bedakan responden.

6. Persetujuan (Informend Consent)

Peneliti menemui lansia yang mengalami gangguan tidur untuk dimint a persetujuan untuk menjadi sampel dala $m$ penelitian. Peneliti akan menjelaskan tujuan dan sifat penelitian, jika responden bersedia maka akan dimintai untuk menandatanga ni lembar persetujuan tetapi jika respond en menolak untuk menjadi sampel maka peneliti tidak akan memaksa dan tetap menghormati haknya.

\section{Pengolahan Data}

Setelah semua data terkumpul maka dilakukan pengolahan data melalui tahap:

a. Editing

Yaitu pengecekan dan pengoreksian data kuesioner yang diisi oleh responden termasuk kelengkapan dan

mengelompokkan kuesioner tersebut dengan menggunakan aspek pengukuran data.

b. Coding

Hasil jawaban kuesioner dari setiap pertanyaan diberi kode sesuai petunjuk. Adapun kode yang digunakan dalam penelitian ini adalah untuk variabel umur digunakan kode 1 untuk umur 30-39 tahun, kode 2 untuk umur 40-49 tahun, dan kode 3 untuk variabel 50-59 tahun. Untuk variabel jenis kelamin digunakan kode 1 untuk laki-laki dan kode 2 untuk perempuan.

c. Entry

Entry adalah memasukan data ke komputer dalam bentuk angka-angka.

d. Tabulating

Untuk memperoleh analisa data dan pengolahan data dimasukkan ke dalam bentuk tabel distribusi frekuensi.

\section{Analisa Data}

a. Analisa Univariat

Analisis univariat dalam penelitian ini bertujuan untuk mendapatkan gambaran distribusi responden serta menggambarkan variabel bebas dan variabel terikat. Analisa univariat dalam penelitian ini dilakukan untuk mengetahui distribusi yang meliputi : umur dan tingkat pendidikan dalam bentuk frekuensi dan persen dan ratarata frekuensi kualitas tidur sebelum dan sesudah dilakukan intervensi dalam bentuk mean dan standar deviasi.

b. Analisa Bivariat

Analisa ini dilakukan untuk mengetahui pengaruh pemberian aromatherapy jahe terhadap penurunan mual dan muntah pada pasien kanker yang menjalani kemoterapi di Rumah Sakit Umum Imelda Pekerja Indonesia Medan Tahun 2017.

\section{HASIL}

\section{Gambaran Umum Tempat Penelitian}

Penelitian ini dilaksanakan di Rumah Sakit Umum Imelda Pekerja Indonesia Medan yang terletak di Jl. Bilal No.24 Pulo Brayan Darat I Medan Timur Penelitian ini dilaksanakan pada bulan Januari - April 2017 pada pasien kanker dengan usia 30 - 59 tahun. Jumlah pasien kanker yang menjalani kemoterapi sebanyak 40 pasien dengan status pasien berulang. sebagian besar pasien berasal dari sekitar Kota Medan dan sebagiannya berasal dari luar kota Medan.

\section{Hasil Penelitian}

Setelah dilakukan penelitian terhadap 30 responden dengan judul Pengaruh Pemberian Aromatherapi Jahe Terhadap Penurunan 
Mual dan Muntah Pada Pasien Kanker yang Menjalani Kemoterapi di Rumah Sakit Umum Imelda Pekerja Indonesia Medan Tahun 2017, maka dapat disajikan data sebagai berikut :

\section{Analisa Univariat}

Tabel 2. Distribusi Frekuensi dan Persentase Karakteristik Umur Responden di RS Imelda Pekerja Indonesia Medan Tahun 2017 $(\mathrm{n}=30)$

\begin{tabular}{lcc}
\hline \multicolumn{1}{c}{ Variabel } & N & \% \\
\hline Umur & & \\
30-39 Tahun & 9 & 30,0 \\
40-49 Tahun & 15 & 50,0 \\
50-59 Tahun & 6 & 20,0 \\
\hline \multicolumn{1}{c}{ Jumlah } & $\mathbf{3 0}$ & $\mathbf{1 0 0}$ \\
\hline
\end{tabular}

Berdasarkan tabel 2 dapat dilihat bahwa umur responden yang berada pada rentang umur 30-39 tahun sebanyak 9 orang $(30,0 \%)$, rentang umur 40-49 tahun sebanyak 15 orang $(50,0 \%)$ sedangkan pada rentang umur 50-59 tahun sebanyak 6 orang $(20,0 \%)$.

Tabel 3. Distribusi Frekuensi dan Persentase Karakteristik Jenis Kelamin Responden di RS Imelda Pekerja Indonesia Medan Tahun 2017 $(\mathrm{n}=30)$

\begin{tabular}{|c|c|c|}
\hline Variabel & $\mathbf{N}$ & $\%$ \\
\hline \multicolumn{3}{|l|}{ Jenis Kelamin } \\
\hline Laki-laki & & 46,6 \\
\hline Perempuan & 16 & 53,3 \\
\hline Jumlah & 30 & 100 \\
\hline
\end{tabular}

Berdasarkan tabel 3 dapat dilihat bahwa mayoritas responden yaitu berjenis kelamin perempuan sebanyak 16 orang $(53,3 \%)$ dan minoritas responden berjenis kelamin lakilaki sebanyak 14 orang $(46,6 \%)$.

Tabel 4. Distribusi Frekuensi Muntah Sebelum diberikan
Mual dan Intervensi
Distribusi Frekuensi Berdasarkan Mual dan Muntah Sebelum Diberikan Intervensi kepada Responden di Rumah Sakit Umum Imelda Pekerja Indonesia Medan Tahun $2017(n=30)$

\begin{tabular}{ccc}
\hline $\begin{array}{c}\text { Kualitas Tidur Sebelum } \\
\text { Intervensi }\end{array}$ & N & \% \\
\hline Mual dan Muntah Iya & 20 & 66,7 \\
\hline Mual dan Muntah Tidak & 10 & 33,3 \\
\hline Total & $\mathbf{3 0}$ & $\mathbf{1 0 0}$ \\
\hline Berdasarkan tabel & 4 & \multicolumn{2}{c}{ didapatkan }
\end{tabular}
mayoritas responden dengan mual dan muntah sebanyak 20 orang $(66,7 \%)$ sedangkan responden dengan Tidak ada mual dan muntah sebanyak 10 orang $(33,3 \%)$.

Tabel 5. Distribusi Frekuensi Mual dan Muntah Sesudah Diberikan Intervensi Distribusi Frekuensi Mual dan Muntah Sesudah Diberikan Kepada Responden di Rumah Sakit Umum Imelda Pekerja Indonesia Medan Tahun 2017 ( $n=30)$

\begin{tabular}{lcc}
\hline $\begin{array}{c}\text { Kualitas Tidur Sesudah } \\
\text { Intervensi }\end{array}$ & N & \% \\
\hline Mual dan Muntah Bertambah & 9 & 30,0 \\
\hline Mual dan Muntah Berkurang & 21 & 70,0 \\
\hline Total & $\mathbf{3 0}$ & $\mathbf{1 0 0}$ \\
\hline Berdasarkan tabel 5 & didapatkan \\
mayoritas responden dengan & mual dan \\
muntah berkurang sebanyak 21 orang \\
$(70,0 \%)$ sedangkan responden dengan mual \\
dan muntah bertambah sebanyak 9 orang \\
$(30,0 \%)$.
\end{tabular}

\section{Analisa Bivariat}

Tabulasi Silang Pengaruh Pemberian AromaTherapi Jahe Terhadap Penurunan Mual dan Muntah Pada Pasien Kanker Yang Menjalani Kemoterapi Di Rumah Sakit Imelda Pekerja Indonesia Medan Tahun 2017. 
Tabel 6. Pengaruh Pemberian Aromatherapi Jahe terhadap Penurunan Mual dan Muntah pada Pasien Kanker yang Menjalani Kemoterapi di Rumah Sakit Imelda Pekerja Indonesia Medan Tahun2017(n=3)

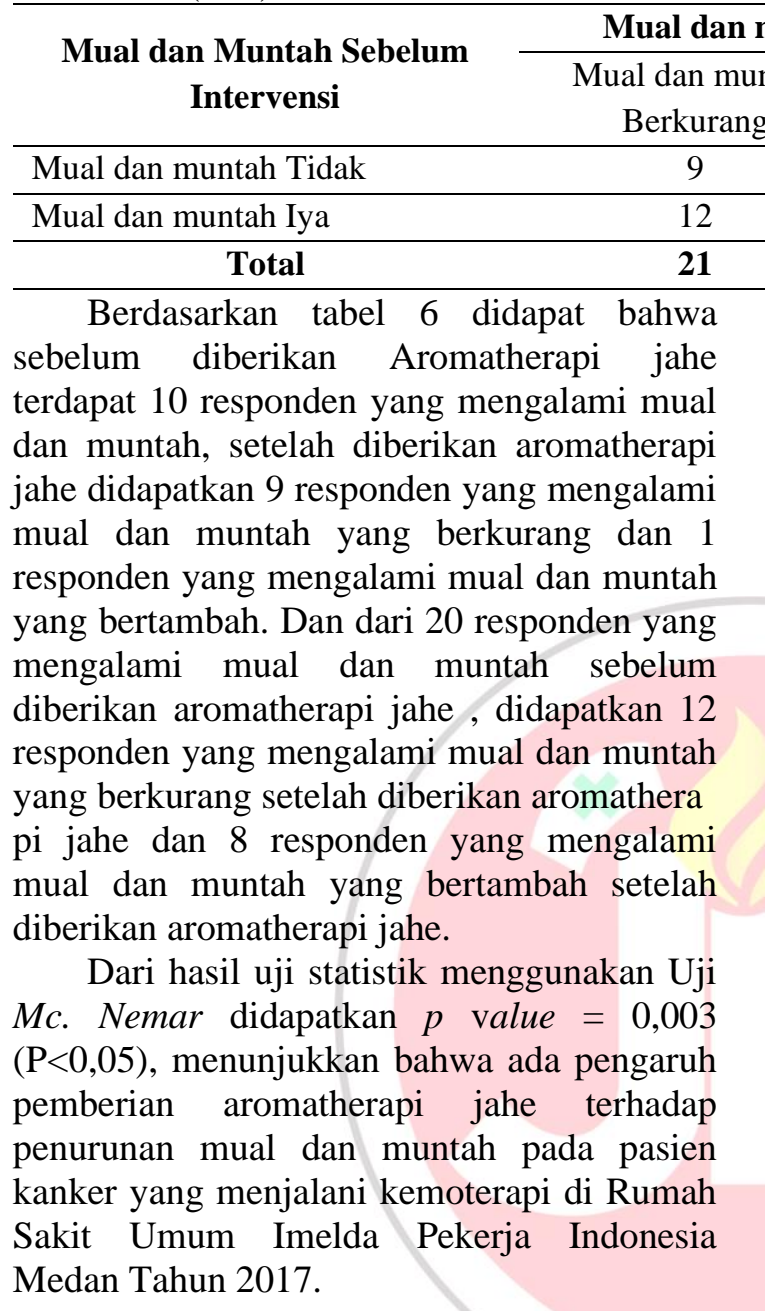

\section{PEMBAHASAN}

Setelah peneliti melakukan penelitian dengan mengumpulkan data dan melakukan teknik analisa data yang dialukan kepada responden tentang Pengaruh pemberian Aromatherapi Jahe terhadap Penurunan Mual dan Muntah Pada pasien kanker yang menjalani Kemoterapi Di Rumah Sakit Umum Imelda pekerja Indonesia Medan., maka peneliti akan melakukan pembahasan hasil penelitian yang ditemukan sebagai berikut:

Pengaruh Pemberian Aroma therapi Jahe terhadap Penurunan Mual dan Muntah pada Pasien kanker yang Menjalani Kemo terapi di Rumah Sakit Umum Imelda Pekerja Indonesia Medan Tahun 2017

Berdasarkan hasil penelitian yang dilakukan di Rumah Sakit Umum Imelda

Pekerja Indonesia Medan Tahun 2017, menunjukkan bahwa ada pengaruh Pemberian Aromatherapi Jahe Terhadap Penurunan Mual dan Muntah pada Pasien kanker yang Menjalani Kemoterapi Di Rumah Sakit Imelda Pekerja Indonesia Medan.

Dalam penelitian ini didapatkan data dari 30 responden yang diteliti menunjukkan bahwa pengaruh pemberian aromaterapi jahe terhadap penurunan mual dan muntah pada pasien kanker yang menjalani kemoterapi di rumah sakit imelda pekerja indonesia medan sekitar 70,0 \% mual dan muntah berkurang dengan pemberian aromaterapi jahe.

Menurut teori Lee ( 2008), Mual dan muntah adalah efek samping yang paling umum dan tidak menyenangkan pada pasien setelah menjalani pengobatan kemoterapi. Insiden mual dan muntah karena efek samping kemoterapi adalah 70-80 \%, beberapa kondisi gejala-gejala yang berhubungan dengan pemberian kemoterapi dapat menurunkan aktivitas sehari-hari pasien kanker dan menyebabkan mereka hanya dapat terbaring ditempat tidur dan tidak bisa memenuhi kebutuhan mereka dalam beraktivitas. Salah satu tindakan keperawatan mandiri seorang perawat yaitu memberikan rasa nyaman untuk mengurangi atau menghilangkan ketidaknyamanan akibat efek samping kemoterapi dengan pemberian terapi komplementer.

Aromaterapi sebagai bagian dari terapi komplementer dapat digunakan untuk meningkatkan kualitas hidup pasien kanker (Boehm, at, al., 2012). Kolcaba mengenalkan teori kenyamanan sebagai middle range theory karena mempunyai tingkat abstraksi yang rendah dan mudah diaplikasikan dalam praktik keperawatan. 
Kenyamanan adalah sebuah tujuan yang sangat diharapkan oleh pasien kanker, dan karenanya menghadirkan tujuan yang penting bagi pelayanan keperawatan, Kolcaba menilai kenyamanan dengan membuat struktur taksonomi yang bersumber pada tiga tipe kenyamanan yaitu reliefe, ease, dan transcendence. Kolcaba mengkaitkan ketiga tipe kenyamanan tersebut dengan empat konteks kenyamanan yaitu fisik, berkaitan dengan sensasi jasmani; Psikospiritual, berkaitan dengan kesadaran diri dan konsep diri; Lingkungan, berkaitan dengan keadaan sekitar; dan sosial berkaitan dengan hubungan interpersonal, keluarga dan sosial.

Tindakan intervensi nonfarmakologi yaitu dengan pemberian aromaterapi jahe ini merupakan bagian dari intervensi comfort yang tujuan memberikan kenyamanan secara fisik pada pasien kanker yang menjalani kemoterapi dengan mengurangi atau menghilangkan mual muntah akibat kemoterapi.

Menurut peneliti bahwa ada pengaruh pemberian aromaterapi jahe terhadap penurunan mual dan muntah pada pasien kanker setelah menjalani kemoterapi , hal ini disebabkan karena aromaterapi jahe yang dapat memblok serotonin yaitu suatu neurotransmitter yang disintesiskan pada neuro-neuro serotonergis dalam sistem saraf pusat dan sel-sel enterokromafin yang dapat memberikan perasaan nyaman sehingga dapat mengatasi mual dan muntah.

\section{KESIMPULAN}

Berdasarkan hasil penelitian yang telah dilakukan mulai dari bulan Januari di Rumah Sakit Umum Imelda Pekerja Indonesia Medan, maka diperoleh Kesimpulan sebagai berikut:

1. Mayoritas responden yang mengalami penurunan mual dan muntah setelah menjalani kemoterapi dengan pemberian aromaterapi jahe sebanyak 21 orang $(70,0)$

2. Dari hasil uji statistik menggunakan Uji Mc. Nemar didapatkan $p$ value $=0,003$ $(\mathrm{P}<0,05)$, menunjukkan bahwa ada pengaruh pemberian aromatherapi jahe terhadap penurunan mual dan muntah pada pasien kanker yang menjalani kemoterapi di Rumah Sakit Umum Imelda Pekerja Indonesia Medan Tahun 2017.

\section{SARAN}

1. Bagi Institusi Pendidikan Keperawatan Diharapkan agar institusi pendidikan dapat meningkatkan kemampuan mahasi swa dengan memberikan materi tentang manfaat aromatherapi jahe terhadap pasien kanker yang menjalani kemoterap i yang mengalami efek samping mual dan muntah.

2. Bagi Pelayanan Kesehatan

Pelayanan kesehatan diharapkan dapat memberikan informasi kepada pasien kanker tentang efek samping dari kemoterapi mual dan muntah setelah menjalani tindakan kemoterapi, hal inidikarenakan tugas seorang perawat adalah sebagai seorang konselor.

3. Bagi Peneliti Selanjutnya

Penelitian ini sebagai dasar peneliti selanjutnya diharapkan untuk melakukan penelitian lebih mendalam/ spesifik lagi tentang Pengaruh pemeberian Aromather api jahe terhadap Penurunan mual dan muntah pada pasien kanker yang menjalani kemoterapi di Rumah Sakit Umum Imelda Pekerja Indonesia Medan.

\section{DAFTAR PUSTAKA}

Alsagaff, Hood. (1995). Kanker Paru dan Terapi Paliatif. Surabaya: Airlangga University Press.

Baradero, Marry dkk. (2007). Seri Asuhan Keperawatan Klien Kanker. Jakarta: EGC.

Delimartha, Setiawan. (2003). Ramuan Tradisonal untuk Pengobatan Kanker. Jakarta: Penebar Swadaya.

Glauss, Agnes, dkk. (2004). Jurnal: Chemotherapy-Induced Nausea And Vomiting In Routine Pravtice a European Perspective volume 12 : 708715.

Indrawati, Maya (2009). Bahaya Kanker bagi Wanita dan Pria. Jakarta: AV Publisher. 
Japaries, Willie. (2007). Pencegahan dan Terapi, Kanker dengan Kombinasi Herbal Indonesia dan Traditional Chinese Medicine. Jakarta: Fakultas Kedokteran UI.

Julie L. Ryan., Charles E. Heckler., Joseph A. Roscoe., Shaker R. Dakhil., Jeffrey Kirshner., Patrick J. Flynn., Jane T. Hickok., Gary R. Morrow. (2012). Ginger (Zingiber Officinale) Reduces Acute Chemotherapy-Induced Nausea: a
URCC CCOP Study of 576 Patients. Support Care Cancer (2012) 20:14791489.

Junaidi， Iskandar. (2007). Kanker. Jakarta: Bhuana Ilmu Popule.

Liau, Chi-Ting dkk. (2005). Incidence of Chemotherapy-Induced Nausea and Vomiting In Taiwan: Physicians and Nurses Estimation vs. Patients' Reported Outcomes Volume 13:277-286.

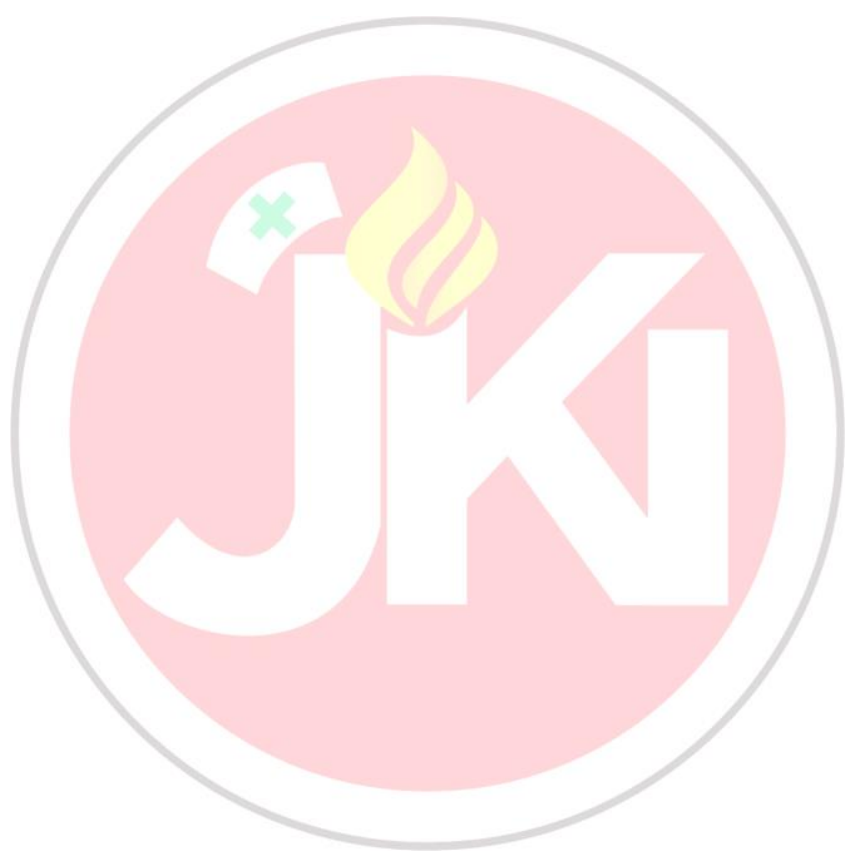

